\title{
Post-modernism, rhetoric and scholasticism at TAG: the current state of British archaeological theory
}

\author{
JOHN BINTLIFF*
}

We reported last year on the course of TAG (Theoretical Archaeology Group) and its annual conferences over several years. This further report reads the meaning of the post-modernist agenda which dominated the most recent TAG conference.

The most important impression from TAG last year (December 1990) at Lampeter University was the palpable evidence for a flourishing intellectual tradition in all branches of British archaeology. Lampeter began as a theological college in a rural corner of Wales, yet some 400 archaeologists made their often tortuous ways there to savour the latest in Theoretical Archaeology. Offers of papers continue to strain the capacity of the 3-4 day meeting, and with three parallel sessions, the quality of competing papers led to much paper-hopping between lecture-rooms. Session organizers, authors of individual papers and the general audience represented a good mix of 'professional' archaeologists (from units, museums and related institutions) and university staff and students, pace Francis Pryor, whose comments on the 'elitism' of TAG (Pryor 1990: 149) reflect a distant prospect of TAG rather than the viewpoint of a TAG regular. The overall conference organization was also excellent.

What of the content of this TAG? Naturally I can only comment on the sessions I attended, or on those I missed but picked up strong reactions from. One highlight was the 'visiting team' session, in the TAG tradition of a session organized around a group of theorists from another (usually European) country. This year Heinrich Härke (Reading) had invited a minibus-load of compatriots to present a session on archaeology in Germany titled All quiet on the Western Front? I was speaking in a parallel session, but heard plentiful reports suggesting that a very illuminating conspectus was offered on developments in - or more to the point, the lack of developments in - German theoretical archaeology.

A unifying theme to nearly all the Lampeter sessions was the dominance of the PostProcessualist (or Post-Modernist) agenda. The irresistible rise of Post-Modernist approaches, the striking feature of the previous two TAGs at Newcastle and Sheffield (cf. Chippindale 1990), was completed at Lampeter where no other general theoretical viewpoint was on show. Appropriately, two of the younger PostProcessualists, Julian Thomas and Chris Tilley, were hosts to the conference.

The very young sub-discipline of (explicit) Archaeological Theory appears to have adopted a habit of total renewal almost every decade. Rather than proceeding in cumulative fashion, deepening our theoretical perspectives, we seem instead to write off the research aims and achievements of each preceding decade. New directions are derived from established and attractive theoretical approaches in other disciplines, rather than via refinements of existing approaches or genuinely internal innovations within archaeology ( $c f$. Bintliff 1986). Ian Hodder, the doyen of Post-Processualism has followed a 'theoretical instability', pulling along a large body of practitioners of theory via the influential, populous body of research students at Cambridge. In the 1970s Ian was advocating the spatial analysis of New Geography (already outdated within geography). Rejecting this for its implied determinism, he moved on to commend Structuralism, particularly in its French anthropological manifestation (despite its being on the wane in all other

* Department of Archaeology, University of Durham, 46 Saddler Street, Durham DH1 3NU. 
disciplines). Dismissing this approach, too, for its behaviouristic determinism, from the mid1980s he has promoted a package of PostModernist approaches, under the guise of 'PostProcessualism'. Needless to say, the PostModernist movement is now widely seen in the humanities as crumbling.

Now it would be foolish to inveigh against the periodic questioning of established concepts in a discipline, and it is actually healthy that archaeological theory discards its old clothes, even though it always reappears in clean but borrowed finery.

However, a remarkable number of PostModern papers at Lampeter received little or no discussion. No genuine debate arose on the strengths and weaknesses of the movement as a guiding programme for theoretical and applied archaeology. Judging by comments picked up from the 'older' delegates (i.e. mid-30s upwards!), the generation which helped to pioneer 'New Archaeology' in Britain in the '60s and early '70s was solidly unenthusiastic about the whole Post-Processual movement - but were not prepared to make public statements. The predominantly 'younger' delegates also seemed to have little to say, confronted by multi-channel Post-Modernist propaganda. Moreover, in the only session deliberately aiming to challenge Post-Processualism, particularly for its critique of 'Archaeological Science'(cf. Fleming \& Johnson 1990: 305-6; Edmonds \& Thomas 1990; Edmonds 1990; Thomas 1990), James Rackham and his scientific colleagues were largely on the defensive, asking for more opportunities to abandon their microscopes and read vogue French philosophers and German sociologists.

This matter of the 'right reading-list' provides a key. Since the 1960s, the proponents of each theoretical renewal programme in archaeology have excluded the preceding generation by reorientating theory around a novel bibliography of intellectual traditions likely to be esoteric and unpalatable to their predecessors who 'write themselves out' of debate by failing to read the new sacred texts. Remember how the New Archaeology claimed that computer illiterates would be intellectually redundant, and bamboozled the 'Traditionalists' with tiresome debates about hypothetico-deductivenomological/empirico-inductive strategies and the like? Post-Processualism asserts, mischie- vously, that useful archaeological theorizing requires continual reference to Lyotard, Lacan, Derrida, Foucault, Heidegger, Habermas, Gadamer and Giddens (none of whom, 'unenlightened' reader, have contributed anything in their writings to the discipline of archaeology - including Foucault's misleadingly-titled The archaeology of knowledge). Those, old and young, who have not read, or do not care for, this new canon are excluded from the new theoretical agenda.

Is this 'Exclusion Principle' a serious criticism of Post-Modernism in archaeology? Yes, in the way the latter's proponents use the technique to legitimize Post-Modernism as the only contemporary paradigm in archaeological theory, - but no, in terms of the potential usefulness of the Post-Modernist theoretical agenda. Nonetheless the criticism does account for the silence of older TAG delegates, who with hardly an exception, will not have read the collected works of these philosophical and sociological luminaries. It also accounts for the silence of younger delegates. University students will face reluctance from their lecturers in including Post-Modernist texts in their reading lists, whilst in the units and museums the pressure on limited time and resources for study will become even more acute if PostModernist authors are to become significant for British archaeology. Hence an audience unable to respond creatively rather than passively to the unadulterated diet of Post-Modernist philosophy served up at the Lampeter TAG.

My impression is also that many in the 'older' generation, who not long ago were organizing innovative TAG sessions, are largely caught up in developed research programmes conceived under preceding approaches, making a paradigm-change in mid course timeconsuming and disorientating.

The positive contribution that a PostModernist perspective can make to archaeology is worth stating. Firstly, its emphasis on a 'critical' examination of the archaeologist's social responsibility offers a valuable antidote to the creeping mindlessness of the 'heritage industry'. (Did you see the media cover of English Heritage's sponsored re-run of the Battle of Hastings? Apparently the Saxons just wouldn't lie down!) Archaeologists should look beyond stamp-collecting typologies and stratigraphic engineering to the broader aims of a 
moral and emotional involvement with 'the past in the present', and thus tap into how the general public actually interacts with the past.

Secondly, Post-Modernism distances us from unquestioning readings of all archaeological publications as 'fact-sheets' at various 'publication levels', in order to refocus on them as expressions of specific culturo-historic attitudes to the past. Thirdly, Post-Modernism encourages multiple views about the past, promoting greater sensitivity to the experience of women in the past, of ethnic minorities, and of the non-élite 'people without history'.

However, it is likely that the drawbacks and weaknesses of the Post-Modernist agenda could debilitate British theoretical archaeology during the 1990s.

Archaeological Post-Processualism has imported, uncritically, the whole spectrum of Post-Modernism, as if it were a unitary programme. In fact, the only thread linking the diverse Post-Modernist theorists is their rejection of the optimistic, Modernist belief in the cumulative accretion since the Enlightenment of true knowledge about human societies, founded on rational enquiry modelled on the hard sciences and mathematics. Beyond that, there is total incompatibility between the Marxist-inspired Critical Theory of Habermas, who believes in the regeneration of a purified Enlightenment rational enquiry through an ethical analysis of human action (freed of 'Modernist', dehumanizing views of people as rational robots), and the Deconstruction Theory of Derrida, Foucault and Gadamer, which dissolves analysis into an endless plurality of interpretations, the concepts of 'valid inference' and 'reality' being rejected as meaningless.

Post-Processualist texts in archaeology find such a critically-unprepared audience that they get away with an agenda that includes such totally contradictory theories. Ian Hodder's Reading the past (1986) vacillates incomprehensibly between a practical programme for reconstructing the intentions behind past behaviour ('Contextual Archaeology'), and a view that we only project modern preconceptions into 'an essentially unknowable past'. During the Lampeter TAG a lecture by Julian Thomas on the Post-Modern approach (sic) to the past landscape employed similarly incompatible intellectual positions. At its conclusion, Mike Rowlands (who will have read the approved authors critically) drew attention to the peculiarity of Julian's intellectual porridge, claiming as it did to find a common attitude to human society in the writings of that active Socialist Raymond Williams and the Nazi mystic Martin Heidegger.

At another Lampeter session, The social role of the urban archaeologist, I expected a coherent professional response to the developer- and 'heritage industry'-led corruption of professional archaeology. To my disillusionment, the overriding message of the session was that there is no 'real historical past' which we should try to uncover. Professional archaeologists should write any narrative that pleases the public, regardless of its relationship to any 'truth' about the past (the latter idea being considered as meaningless anyway). Here the active relativism at one end of the Post-Modernist spectrum is offering a disturbing redefinition of the rôle of the professional archaeologist towards the public. Since the most popular books on the past are by Astro-Archaeologists, and, in parts of the States, by Fundamentalists, are we now to devote gallery and site-publication space to their 'narratives'? What about the National Front - whose racist views are underrepresented in the archaeological media - who are we to privilege our historically-imposed bias of liberal thought?

This attitude represents a total abdication of responsibility by archaeologists to their real duty to contemporary society. Beyond 'entertaining' and 'giving the public its money's worth', professional archaeologists have a more fundamental duty: to uncover the evidence of 'what actually happened' (sic) so as to prevent the fabrication of the past by those who might manipulate it to suit a priori ideologies of Left, Centre, Right, Green, Ethnic, Sexist or Feminist factions in contemporary society.

If Post-Modernists demand a plurality of interpretations, why should we listen to any of theirs as opposed to any other of the infinite range of methodologies and philosophies available in world literature? One weak response by the Post-Modernists is to elevate Rhetoric as a guiding principle: it will not be the 'facts of the case' that should persuade you, but the emotional sway engendered by powerful word-play and charismatic texts. The Lampeter TAG offered a show-case example when John Barrett (in the Constructing landscape session), 
gave us a familiar harangue on the Marxist view of the human past, touching at no point on any archaeological or historical specifics. As rhetoric it was entertaining, but at the same time it has to be ironic that a highly-educated TAG audience should receive, in silence, a partypolitical broadcast on behalf of an ideological movement whose former adherents have been deserting it in millions over the last couple of years. The anti-positivist attitude fostered by mainstream Post-Modernism would take European thought back towards a pre-scientific, pre-rational, pre-Enlightenment and preRenaissance era - the Middle Ages - when indeed we can substitute for the modern ideals of 'Knowledge' and 'Analysis' those of Rhetoric (word-skills rate more than truth to facts) and Scholasticism (the value of a theory rests upon the summed names of famous thinkers who support it).

In reality, many of the truly useful insights of Post-Modernism (those more in the Habermasian than Deconstructive vein), can be harnessed into a constructive twosome with positivist, 'realist', 'scientific' research, as has already been argued by Colin Renfrew (1982) and myself $(1986 ; 1988 ; 1991)$.

Were one to contemplate such a way forward of peaceful co-operation and constructive dialectic of Processual and Post-Processual approaches, it would still remain essential that such an improved framework for the discipline of archaeology should rest upon a firm foundation: empirical data-collection, rigorous datadescription, and the analysis of all potentially significant associations between artefacts, ecofacts and structures and their stratigraphical, cultural and ecological contexts. If you do not believe such an agreed 'core' can exist, then I see no point in continuing a 'profession' of archaeologist. The thesis that the archaeological record comes to light as empirical data existing in objectively patterned association, as a separate phenomenon from the contentious sphere of behavioural interpretation, must be the basis for any hopes of adjudication between all or any theories about the kinds of human activity which gave rise to certain properties in the data.

When we move beyond this basic level of data-collection, description and patternrecognition, we certainly rapidly enter the operational area for models and hypotheses, many difficult to verify or falsify and deriving as much from personal philosophies and ideologies as from observation of the data under analysis.

Julian Thomas saw this 'pyramid of inference' (in the discussion following the same Landscape session) as a restatement of Christopher Hawkes' 'infamous' 1954 paper on the limitations of archaeological inference. Although I can't agree with Hawkes that firm interpretations beyond the economic and technological spheres will always lie beyond our capabilities, the last 37 years have repeatedly confirmed his grain of truth: that reliable reconstructions do become increasingly difficult and controversial when we address the social and psychological. A more appropriate ancestor for my position would be General Pitt-Rivers, one of the key figures in the establishment of empirical, scientific archaeology, who demanded of excavators that they record and keep all that they find and observe, even if much of it appears of no obvious value at the time; the records will be there when future archaeologists come to them with new questions. When Pitt-Rivers 'entered' the discussion, Barbara Bender, from the audience, reminded us that he was a virulent racist in his interpretations of history (and one might add, unpleasantly right-wing in his other opinions). Pitt-Rivers, like the rest of us, was impelled along his researches by subjective prejudices. Yet Pitt-Rivers' case demonstrates strikingly that one can and must separate empirical research from the variable motives which led to data collection and the use or abuse of that data to tell stories about the past. For all his interpretative bigotry, Pitt-Rivers' fieldwork and excavation records are so refined that Richard Bradley (who, despite training as a lawyer in a previous existence, is certainly neither a racist nor a fascist), in re-excavating some of PittRivers' sites, has been able to reinterpret them on the basis of details recorded a century ago of which the General was unable to understand the significance (cf. Barrett et al. 1990).

In any case, the too-often repeated charge of Post-Processualists, that all archaeologists seek out data in the blind service of their subjective ideologies, may suit aristocratic right-wing eccentrics like Pitt-Rivers, or middle-class leftwing intellectuals in comfortable academic circumstances feeling uneasy with their social consciences, but bears little relationship to the realities of most professional and academic 
archaeological research programmes. Where, pray, does the unit director's personal ideology intervene in choice of data, when a major slice in the midst of his historic town is threatened by rapid redevelopment? On a personal note, like most regional survey specialists, I simply cannot imagine what kinds of patterned behaviour may be awaiting our project in the field in each new season, nor where ultimately the information we are recording might lead to in terms of the picture we will obtain of the vicissitudes of past societies. This element of 'surprise' is perhaps a distinctive feature of the presence of an autonomous empirical element in research as opposed to entirely theory-led programmes.

In conclusion, if you want to find out more about this rampant monster of Post-Processualism, I recommend a sceptical approach that mixes reading the original Post-Modernist masters with the powerful criticisms their work has evoked. I remain unconvinced that the main body of this intellectual movement will 'bear fruit' in terms of enabling us to get closer to describing and interpreting what actually hap-

\section{References}

BARRETT, J., R. BRADLEY \& M. GREEN. 1990. Landscape, monuments and society: the prehistory of Cranborne Chase. Cambridge: Cambridge University Press.

BINTLIFF, J.L. 1986. Archaeology at the interface: an historical perspective, in J.L. Bintliff \& C.F. Gaffney (ed.), Archaeology at the interface: 4-31. Oxford: British Archaeological Reports. International series $\mathrm{S} 300$.

(ed.). 1988. Extracting meaning from the past. Oxford: Oxbow Books.

(ed.). 1991. The Annales School and archaeology. Leicester: Leicester University Press.

CHIPPINDALE, C. 1990. Theoretical Archaeology Group: 11th Conference, Current Anthropology 31: 463-6.

EDMONDS, M. 1990. Science, technology and society, Scottish Archaeological Review 7: 23-30.

EDMONDS, M. \& J. Thomas. 1990. Science fiction: pened in the past. That small remaining part of Post-Modernism which has got something to offer centres on two things: an interest in human motivations, which is merely an extension of a growing research area within the most recent phase of Processual archaeology ( $c f$. Renfrew's 'cognitive archaeology'); and a commitment to make archaeology more emotionally and morally challenging, which, likewise, was a growing theme within New Archaeology and has been discussed with greater sophistication as 'reflexive archaeology' within the most recent phase of that tradition (cf. Wilk 1985).

As for the greater part of Post-Modernism with its determination to topple science, reason, truth, objectivity, a 'real past', and professional responsibility, from their privileged status in the hearts and minds of serious researchers, - well, fellow archaeologists, if you do feel tempted to respond to the frantic signals of its local practitioners the Post-Processualists, - be advised that, in the words of that poignant poem by Stevie Smith, they are 'Not waving, but drowning'.

scientism and technism in archaeology, Scottish Archaeological Review 7: 1-2.

Fleming, A. \& M. JoHnson. 1990. The Theoretical Archaeology Group (TAG): origins, retrospect, prospect, Antiquity 64: 303-7.

HAWKES, C.F.C. 1954. Archaeological theory and method: some suggestions from the Old World, American Anthropologist 56: 155-68.

HODDER, I. 1986. Reading the past. Cambridge: Cambridge University Press.

PRYOR, F. 1990. The reluctant greening of archaeology, Antiquity 64: 147-50.

RENFREW, A.C. 1982. Towards an archaeology of mind. Cambridge: Cambridge University Press.

THOMAS, J. 1990. Silent running: the ills of environmental archaeology, Scottish Archaeological Review 7: 2-7.

WILK, R.R. 1985. The ancient Maya and the political present, Journal of Anthropological Research 41: 307-26. 